\title{
FAKTOR-FAKTOR YANG MEMPENGARUHI KEJADIAN KELAHIRAN PRETERM DI RSUD BANYUASIN TAHUN 2017-2018
}

\author{
Vera Yuanita \\ Program Studi DIII Keperawatan, DIII Kebidanan STIKES Mitra Adiguna Palembang \\ Komplek Kenten Permai Blok J No.9-12 Bukit Sangkal Palembang 30114 \\ Email ; v.yuanita72@gmail.com
}

\begin{abstract}
Abstrak
Kelahiran preterm merupakan penyebab utama (60-80\%) morbiditas dan mortalitas neonatal diseluruh dunia. Kelahiran preterm terjadi pada masa kehamilan kurang dari 37 minggu dengan berat janin kurang dari 2500 gram. Angka kejadian kelahiran preterm di Indonesia sekitar 19\% dan merupakan penyebab utama kematian perinatal. Beberapa factor risiko yang menyebab kanter jadinya kelahiran preterm yaitu faktor yang terjadi selama kehamilan seperti pecahnya selaput ketuban, perdarahan antepartum, kehamilan ganda, hidramnion, penyakit sistemik kronis pada ibu. Faktor epidemiologi ibu seperti umur, paritas dan social ekonomi juga menjadi penyebab terjadinya kelahiran preterm. Jenis penelitian adalah analitik kuantitatif dengan desain kasus kontrol. Sampel kasus adalah ibu yang melahirkan bayi yang didiagnosis preterm yang memenuhi kriteria dan sampel kontrol adalah ibu yang melahirkan bayi dengan usia kehamilan $\geq 37$ minggu di RSUD Banyuasin. Hasil penelitian menunjukkan tidak ada hubungan yang signifikan antara umur ibu $(p=0,098)$ dan paritas $(p=0,136)$ dengan kelahiran preterm. Ada hubungan yang signifikan antara anemia $(p=0,000), P E B(p=0,017)$ dan $K P D(p=0,000)$ dengan kelahiran preterm. Analisis multivariat menunjukkan KPD adalah variabel yang paling berpengaruh terhadap kelahiran preterm $(O R=4,369)$. Diharapkan petugas kesehatan dapat memberikan konseling kehamilan serta memberikan pelayanan antenatal care sesuai standar sehingga anemia, ketuban pecah dini, preeklampsialeklampsia dapat dicegah dan tidak berdampak persalinan prematur.
\end{abstract}

Kata Kunci : Kelahiran Preterm, Umur, Paritas, Anemia, PEB dan KPD

\begin{abstract}
Preterm birth is the main cause (60-80\%) of neonatal morbidity and mortality worldwide. Preterm birth occurs during pregnancy less than 37 weeks with a fetal weight of less than 2500 grams. The incidence of preterm birth in Indonesia is around 19\% and is the main cause of perinatal death. Some risk factors that cause preterm birth are factors that occur during pregnancy such as rupture of the membranes, antepartum bleeding, multiple pregnancies, hydramnions, chronic systemic diseases in the mother. Epidemiological factors of the mother such as age, parity and socio-economic are also the causes of preterm birth. This type of research is quantitative analytic with case control design. Case samples were mothers who gave birth to babies who were diagnosed with preterm who met the criteria and control samples were mothers who gave birth to babies with gestational age $\geq 37$ weeks in Banyuasin General Hospital. The results showed no significant relationship between maternal age $(p=0.098)$ and parity $(p=0.136)$ with preterm birth. There was a significant relationship between anemia $(p=0,000)$, Severe preeclampsia $(p=0,017)$ and Premature rupture of membranes $(p=0,000)$ with preterm birth. Multivariate analysis showed that Premature rupture of membranes was the most influential variable on preterm birth $(O R=4.369)$. It is expected that health workers can provide pregnancy counseling and provide antenatal care services according to standards so that anemia, premature rupture of membranes, preeclampsia / eclampsia can be prevented and does not affect preterm labor.
\end{abstract}

Keywords: Preterm birth, age, parity, anemia, preeclampsia and premature rupture of membranes 


\section{PENDAHULUAN}

Kelahiran preterm terjadi pada masa kehamilan kurang dari 37 minggu (antara 20-37 minggu) yang dihitung dari haid pertama haid terakhir dengan berat janin kurang dari 2500 gram. maka alat-alat vital (otak, jantung, paru, ginjal) belum sempurna, sehingga mengalami kesulitan dalam adaptasi untuk tumbuh dan berkembang dengan baik (Kusumawati dkk, 2011).

Kelahiran kurang bulan dikategorikan sebagai kelahiran yang terjadi pada kelahiran kurang bulan spontan (rata-rata 45-50 \% kasus), atau pecah ketuban spontan (rata-rata 30-35\% kasus), atau kelahiran kurang bulan atas indikasi bayi atau ibu seperti hipertensi, solusio plasenta, plasenta previa dan lainnya (rata-rata 20\% kasus) (Goldenberg RL, 2010, Cunningham, 2014).

Distribusi kejadian kelahiran preterm berdasarkan usia yaitu berkisar 71,2\% pada usia kehamilan 34-36 minggu, 12,7\% pada 32-33 minggu, $10 \%$ pada $28-31$ minggu dan $6 \%$ pada kurang dari 28 minggu (Cunningham, 2014).

Mekanisme terjadinya kelahiran preterm sampai saat ini masih menjadi perdebatan. Terdapat empat mekanisme yang mungkin menyebabkan terjadinya kelahiran preterm, yaitu pertama adanya hipothalamic-pituitary-adrenal axis dari janin dan ibu. Mekanisme ini terjadi karena stres fetomaternal yang merangsang pelepasan corticotropin realising hormone (CRH) yang mengakibatkan perubahan regulasi hormon estrogen dan progesteron. Kedua adalah inflamasi sistemik atau inflamasi pada desidua dan korioamnion. Mekanisme ini mendukung kejadian infeksi sebagai penyebab kelahiran preterm. Ketiga adalah perdarahan desidua yang menyebabkan solusio plasenta dan keempat adalah distensi uterus yang patologis seperti kehamilan ganda, polihidramnion dan kelainan uterus (Ramsey PS, 2000).

Kelahiran preterm merupakan masalah multi faktor. Berbagai penelitian telah dilakukan untuk mencari faktor- faktor risiko kelahiran preterm. Namun, adanya factor risiko tersebut tidak selalu menyebabkan terjadinya kelahiran preterm. Sebagian kelahiran preterm yang terjadi secara spontan tidak memiliki factor risiko yang jelas). Tidak ada factor pasti yang dapat menyebabkan preterm sehingga pencegahan melalui satu atau beberapa factor mungkin tidak akan berhasil. Oleh karena itu, jika ingin mengurangi jumlah kelahiran preterm, maka langkah pertama untuk mencegah kelahiran preterm adalah dengan mengurangi factor risiko yang berhubungan dengan kelahiran preterm.

Beberapa faktor yang dapat menyebabkan terjadinya kelahiran preterm, yaitu pada maternal, fetal dan plasenta serta sosial ekonomi. Keadaan ibu yang sering menyebabkan persalinan preterm, yaitu infeksi saluran kemih, infeksi, penyakit ibu seperti hipertensi selama kehamilan, asma, penyakit jantung , kecanduan obat, kolestatis, anemia, keadaan yang menyebabkan distensi, isoimunisasi Rh, perdarahan antepartum, korioamnionitis, infeski umum pada ibu, tindakan bedah selama kehamilan, dan kehamilan dengan AKDR. Keadaan janin yang menyebabkan persalinan preterm, yaitu sukar bernafas, kesukaran pemberian minum, ikhterus berat, infeksi, dan riwayat kelahiran preterm (memiliki risiko mengalami persalinan preterm 20 kali lebih tinggi). (Rini et a, 2017).

\section{METODE PENELITIAN}

Jenis penelitian yang digunakan adalah penelitian analitik kuantitatif dengan rancangan atau desain studi kasus kontrol (case control study) yang dilakukan secara retrospektif. Penelitian dilaksanakan di RSUD Banyuasin.

Populasi penelitian terdiri dari populasi kasus dan populasi kontrol, yang selanjutnya akan diambil sebagai sampel 
penelitian. Sampel kasus dalam penelitian ini adalah ibu yang melahirkan bayi yang didiagnosis preterm yang memenuhi kriteria dan tercatat dalam data rekam medis rumah sakit. Adapun kriteria untuk sampel kasus adalah Ibu yang melahirkan dengan usia kehamilan < 37 minggu di RSUD Banyuasin dan tidak memiliki penyakit/komplikasi penyerta seperti penyakit jantung, plasenta previa, gemelli, perdarahan antepartum, dll). Cara pengambilan sampel kasus dilakukan dengan cara purposive sampling. Jumlah kelompok kasus adalah 84 responden, tetapi dalam proses pengambilan sampel ditemukan data rekam medis yang kurang lengkap dan tidak memenuhi kriteria kelompok kasus sehingga diperoleh jumlah sampel kasus adalah 60 .

Untuk kriteria sampel kontrol adalah ibu yang melahirkan bayi dengan usia kehamilan $\geq 37$ minggu di RSUD Banyuasin. Sampel kasus berjumlah 60 sedangkan jumlah sampel kontrol menggunakan perbandingan kelompok kasus : kelompok kontrol yaitu 1:1. Jadi jumlah sampel kontrol adalah 60, sehingga total sampel penelitian adalah jumlah sampel kasus (kelahiran preterm) dan jumlah sampel kontrol (kelahiran aterm) yaitu 120. Teknik pengambilan sampel kasus adalah dengan systematic random sampling.

Data sekunder dalam penelitian ini berupa data rekam medik dengan cek list pasien dengan persalinan preterm di RSUD Banyuasin tahun 2017 dan 2018.

Analisis penelitian meliputi analisis univariat, analisis bivariat dan multivariat, analisis univariat dilakukan untuk menghasilkan distribusi frekuensi dari tiap variabel. Analisa bivariat adalah analisa data untuk mengetahui hubungan antara variabel independen dengan variabel dependen yang dianalisis dengan uji statistik chi-square $\left(\mathrm{x}^{2}\right)$ dengan taraf signifikan $(\alpha)=0,05$. Dalam analisis mutivariat digunakan metode analisis regresi logistik.
HASIL PENELITIAN

\section{Analisis Univariat \\ a. Kelahiran Preterm}

Tabel 1

Distribusi Frekuensi Kejadian

Kelahiran Preterm di RSUD

Banyuasin Tahun 2017-2018

\begin{tabular}{ccc}
\hline $\begin{array}{c}\text { Kelahiran } \\
\text { Preterm }\end{array}$ & Jumlah & $\begin{array}{c}\text { Persentase } \\
(\boldsymbol{\%})\end{array}$ \\
\hline Ya & 60 & 50 \\
Tidak & 60 & 50 \\
\hline Total & 120 & 100 \\
\hline
\end{tabular}

b. Umur Ibu

Tabel 2

Distribusi Frekuensi Umur Ibu di RSUD Banyuasin

Tahun 2017-2018

\begin{tabular}{lcc}
\hline UmurIbu & Jumlah & $\begin{array}{c}\text { Persentase } \\
(\mathbf{\%})\end{array}$ \\
\hline RisikoTinggi & 53 & 44,2 \\
Risiko Rendah & 67 & 55,8 \\
\hline Total & 120 & 100 \\
\hline
\end{tabular}

\section{c. Paritas}

Tabel 3

Distribusi Frekuensi Paritas di

RSUD Banyuasin

Tahun 2017-2018

\begin{tabular}{lcc}
\hline Paritas & Jumlah & $\begin{array}{c}\text { Persentase } \\
(\mathbf{\%})\end{array}$ \\
\hline RisikoTinggi & 48 & 40 \\
Risiko Rendah & 72 & 60 \\
\hline Total & 120 & 100 \\
\hline
\end{tabular}


d. Anemia

Tabel 4

Distribusi Frekuensi Anemia di RSUD

Banyuasin

Tahun 2017-2018

\begin{tabular}{lcc}
\hline Anemia & Jumlah & $\begin{array}{c}\text { Persentase } \\
(\boldsymbol{\%})\end{array}$ \\
\hline Ya & 26 & 21,7 \\
Tidak & 94 & 78,3 \\
\hline Total & 120 & 100 \\
\hline
\end{tabular}

e. Ketuban Pecah Dini

Tabel 5

Distribusi Frekuensi Ketuban Pecah

Dini di RSUD Banyuasin

Tahun 2017-2018

KPD Jumlah Persentase

\begin{tabular}{lcc} 
& & $(\boldsymbol{\%})$ \\
\hline Ya & 55 & 40 \\
Tidak & 65 & 60 \\
\hline Total & 120 & 100 \\
\hline
\end{tabular}

f. PEB

Tabel 6

Distribusi Frekuensi Pre Eklampsia Berat (PEB) di RSUD Banyuasin Tahun 2017-2018

\begin{tabular}{lcc}
\hline PEB & Jumlah & $\begin{array}{c}\text { Persentase } \\
(\boldsymbol{\%})\end{array}$ \\
\hline Ya & 36 & 30 \\
Tidak & 84 & 70 \\
\hline Total & 120 & 100 \\
\hline
\end{tabular}

2. Analisis Bivariat

a. Hubungan umur ibu dengan kelahiran preterm

\section{Tabel 7}

Distribusi Responden menurut Umur Ibu dan Kelahiran Preterm di RSUD Banyuasin Tahun 2017-2018

\begin{tabular}{|c|c|c|c|c|c|c|}
\hline \multirow{3}{*}{$\begin{array}{l}\text { UmurI } \\
\text { bu }\end{array}$} & \multicolumn{4}{|c|}{ Kelahiran Preterm } & \multirow{3}{*}{$\underset{\text { value }}{p}$} & \multirow{3}{*}{$\begin{array}{c}\text { OR } \\
95 \% \mathrm{CI}\end{array}$} \\
\hline & \multicolumn{2}{|c|}{ Ya } & \multicolumn{2}{|c|}{ Tidak } & & \\
\hline & $\mathbf{n}$ & $\%$ & $\mathbf{n}$ & $\%$ & & \\
\hline $\begin{array}{l}\text { Risiko } \\
\text { Tinggi }\end{array}$ & 31 & 51,7 & 22 & 36,7 & \multirow[t]{3}{*}{0,141} & \multirow{3}{*}{$\begin{array}{c}1,846 \\
(0,890- \\
3,829)\end{array}$} \\
\hline $\begin{array}{l}\text { Risiko } \\
\text { Rendah }\end{array}$ & 29 & 48,3 & 38 & 63,3 & & \\
\hline Total & 60 & 100 & 60 & 100 & & \\
\hline
\end{tabular}

b. Hubungan paritas dengan kelahiran preterm

Tabel 5.8

Distrubusi Responden menurut Paritas dan Kelahiran Preterm di RSUD Banyuasin Tahun 2017-2018

\begin{tabular}{|c|c|c|c|c|c|c|}
\hline \multirow{3}{*}{ Paritas } & \multicolumn{4}{|c|}{ Kelahiran Preterm } & \multirow{3}{*}{$\begin{array}{c}p \\
\text { value }\end{array}$} & \multirow{3}{*}{$\begin{array}{c}\text { OR } \\
95 \% \mathrm{CI}\end{array}$} \\
\hline & \multicolumn{2}{|c|}{ Ya } & \multicolumn{2}{|c|}{ Tidak } & & \\
\hline & $\mathbf{n}$ & $\%$ & $\mathbf{n}$ & $\%$ & & \\
\hline $\begin{array}{l}\text { Risiko } \\
\text { Tinggi }\end{array}$ & 28 & 46,7 & 20 & 33,3 & \multirow[t]{3}{*}{0,192} & \multirow{3}{*}{$\begin{array}{r}1,750 \\
(0,836- \\
3,662)\end{array}$} \\
\hline $\begin{array}{l}\text { Risiko } \\
\text { Rendah }\end{array}$ & 32 & 53,3 & 40 & 66,7 & & \\
\hline Total & 60 & 100 & 60 & 100 & & \\
\hline
\end{tabular}

\section{c. Hubungan anemia dengan kelahiran preterm}

Tabel 9

Distribusi Responden menurut Anemia dan Kelahiran Preterm

di RSUD Banyuasin Tahun 2017-2018

\begin{tabular}{lcccccc}
\hline \multirow{2}{*}{ Anemia } & \multicolumn{4}{c}{ Kelahiran Preterm } & \multirow{2}{*}{$\boldsymbol{p}$} & \multirow{2}{*}{ OR } \\
\cline { 2 - 5 } & \multicolumn{2}{c}{ Ya } & \multicolumn{2}{c}{ Tidak } & \multirow{2}{*}{ value } & $\mathbf{9 5 \% \mathbf { C I }}$ \\
\cline { 2 - 5 } & $\mathbf{n}$ & $\boldsymbol{\%}$ & $\mathbf{n}$ & $\mathbf{\%}$ & & \\
\hline Ya & 21 & 35 & 5 & 8,3 & 0,001 & 5,923 \\
Tidak & 39 & 65 & 55 & 91,7 & & $(2,056-$ \\
\hline Total & 60 & 100 & 60 & 100 & & $17,06)$ \\
\hline
\end{tabular}

d. Hubungan KPD dengan kelahiran preterm

Tabel 10

Distribusi Responden menurut

Ketuban Pecah Dini (KPD) dan

Kelahiran Preterm di RSUD Banyuasin Tahun 2017-2018

\begin{tabular}{lcccccc}
\hline KPD & \multicolumn{4}{c}{ Kelahiran Preterm } & \multirow{p}{*}{$\begin{array}{c}\text { OR } \\
\end{array}$} & \multicolumn{2}{c}{ Ya } & \multicolumn{2}{c}{ Tidak } & value & 95\% CI \\
\cline { 2 - 5 } & $\mathbf{n}$ & $\mathbf{\%}$ & $\mathbf{n}$ & $\mathbf{\%}$ & & \\
\hline Ya & 38 & 63,3 & 17 & 28,3 & 0,000 & 4,369 \\
\hline Tidak & 22 & 36,7 & 43 & 71,7 & & $(2,025-$ \\
\hline Total & 60 & 100 & 60 & 100 & & $9,424)$ \\
\hline
\end{tabular}




\section{e. Hubungan PEB dengan kelahiran preterm}

Tabel 11

Distribusi Responden menurut Pre Eklampsia Berat (PEB) dan Kelahiran Preterm di RSUD Banyuasin Tahun 2017-2018

\begin{tabular}{lcccccc}
\hline & \multicolumn{4}{c}{ Kelahiran Preterm } & & \multirow{2}{*}{ OR } \\
\cline { 2 - 5 } PEB & \multicolumn{2}{c}{ Ya } & \multicolumn{2}{c}{ Tidak } & value & 95\% CI \\
\cline { 2 - 5 } & $\mathbf{n}$ & $\mathbf{\%}$ & $\mathbf{n}$ & $\mathbf{\%}$ & & \\
\hline Ya & 24 & 40 & 12 & 20 & 0,028 & 2,667 \\
Tidak & 36 & 60 & 48 & 80 & & $(1,178-$ \\
\hline Total & 60 & 100 & 60 & 100 & & $6,034)$ \\
\hline
\end{tabular}

\section{Analisis Multivariat}

\section{a. Pemilihan Kandidat Model}

Tabel 12.

Hasil Seleksi Bivariat antara Variabel Independen dengan Kelahiran Preterm

\begin{tabular}{ccccc}
\hline $\begin{array}{c}\text { N } \\
\text { o. }\end{array}$ & Variabel & $\begin{array}{c}\text { Log- } \\
\text { Likelihood }\end{array}$ & G & $\begin{array}{c}\mathbf{P} \\
\text { Value }\end{array}$ \\
\hline 1 & Umuribu & 163,607 & 2,748 & 0,097 \\
\hline 2 & Paritas & 164,125 & 2,230 & 0,135 \\
\hline 3 & Anemia & 153,032 & 13,324 & 0,000 \\
\hline 4 & KPD & 151,222 & 15,133 & 0,000 \\
\hline 5 & PEB & 160,558 & 5,798 & 0,016 \\
\hline
\end{tabular}

Dari tabel 12. Hasil analisis kandidat model didapatkan dari 5 variabel tersebut semuanya memiliki $p$ value $<0,25$ sehingga dapat masuk kedalam model multivariat.

\section{b. Pemodelan Multivariat \\ Model 1.}

Hasil Analisis Multivariat Regresi Logistik antara variabel Independen dengan kelahiran preterm

\begin{tabular}{lcccc}
\hline Variabel & B & $\begin{array}{c}\boldsymbol{p} \\
\text { wald }\end{array}$ & OR & $\begin{array}{c}\mathbf{9 5 \%} \\
\text { CI }\end{array}$ \\
\hline Umuribu & 1,066 & 0,141 & 2,904 & $0,703-$ \\
& & & & 11,995 \\
\hline Paritas & $-2,143$ & 0,038 & 0,117 & $0,015-$ \\
& & & & 0,888 \\
\hline Anemia & 1,623 & 0,035 & 5,066 & $1,117-$ \\
& & & & 22,975 \\
\hline KPD & 2,529 & 0,005 & 12,538 & $2,180-$ \\
& & & & 72,123 \\
\hline PEB & $-1,117$ & 0,148 & 0,327 & $0,072-$ \\
& & & & 1,486 \\
\hline Constant & $-0,732$ & 0,010 & 0,481 & \\
\hline
\end{tabular}

2 Log likelihood $=140,10 \quad G=26,250 p$ value $=0,000$
Dari hasil di atas terlihat bahwa siginfikansi log-likelihood $<0,05(\mathrm{p}=0,000)$. Namun secara signifikan $p$ wald variabel umur ibu dan PEB $p$ value $>0,05$. Dengan demikian perlu dilakukan pengeluaran variabel dari model. Pengeluaran variabel dilakukan bertahap satu per satu dimulai dari variabel yang $p$ valuenya tertinggi. Untuk hasil diatas terlihat bahwa variabel umur ibu dan PEB mempunyai $p$ value terbesar, tetapi variabel PEB dianggap mempunyai pengaruh langsung terhadap kelahiran preterm dibandingkan dengan umur ibu sehingga variabel PEB tetap dipertahankan di dalam model, untuk itu proses model selanjutnya dengan tidak mengikuti variabel umur ibu. Hasil model tanpa variabel umur ibu terlihat pada model kedua berikut ini.

\section{Model 2.}

Hasil Analisis Multivariat Regresi Logistik antara Paritas, Anemia, KPD dan PEB dengan kelahiran preterm

\begin{tabular}{lcccc}
\hline & B & $\begin{array}{c}\boldsymbol{p} \\
\text { wald }\end{array}$ & OR & $\begin{array}{c}\mathbf{9 5 \%} \\
\text { CI }\end{array}$ \\
\hline Paritas & $-1,180$ & 0,141 & 0,307 & $0,064-$ \\
& & & & 1,478 \\
\hline Anemia & 1,488 & 0,049 & 4,430 & $1,004-$ \\
& & & & 19,543 \\
\hline KPD & 2,491 & 0,005 & 12,078 & $2,083-$ \\
& & & & 70,036 \\
\hline PEB & $-1,118$ & 0,146 & 0,327 & $0,073-$ \\
& & & & 1,474 \\
\hline Constant & $-0,599$ & 0,025 & 0,549 & \\
\hline Log ilkelihood
\end{tabular}

\section{Log likelihood $=142,280 \mathrm{G}=24,076$} $p$ value $=0,000$

Hasil analisis diatas ternyata variabel paritas mempunyai $\mathrm{p}$ value sebesar 0,141. Dengan hasil ini berarti variabel paritas dikeluarkan dari model. Kemudian diproses lagi dengan hanya mengikutkan variabel independen anemia, KPD dan PEB. Hasil model tanpa variabel paritas terlihat pada model ketiga berikut ini: 


\section{Model 3.}

Hasil Analisis Multivariat Regresi Logistik antara Anemia, KPD dan PEB dengan kelahiran preterm

\begin{tabular}{|c|c|c|c|c|}
\hline Variabel & B & $\underset{\text { wald }}{p}$ & OR & $\begin{array}{c}95 \% \\
\text { CI }\end{array}$ \\
\hline Anemia & 1,750 & 0,020 & 5,753 & $\begin{array}{l}1,321- \\
25,042\end{array}$ \\
\hline KPD & 1,583 & 0,007 & 4,869 & $\begin{array}{l}1,534- \\
15,457\end{array}$ \\
\hline PEB & $\begin{array}{c}- \\
1,294 \\
\end{array}$ & 0,092 & 0,274 & $\begin{array}{c}0,061- \\
1,234 \\
\end{array}$ \\
\hline Constant & $\begin{array}{c}- \\
0,670\end{array}$ & 0,011 & 0,512 & \\
\hline
\end{tabular}

Hasil analisis diatas ternyata variabel PEB mempunyai $\mathrm{p}$ value sebesar 0,092. Dengan hasil ini berarti variabel PEB dikeluarkan dari model. Kemudian diproses lagi dengan hanya mengikutkan variabel independen anemia dan KPD. Hasil model tanpa variabel PEB terlihat pada model keempat berikut ini :

Model 4.

Hasil Analisis Multivariat Regresi Logistik antara Anemia dan KPD dengan kelahiran preterm

\begin{tabular}{lcccc}
\hline Variabel & B & $\begin{array}{c}\boldsymbol{p} \\
\text { wald }\end{array}$ & OR & $\begin{array}{c}\mathbf{9 5 \%} \\
\text { CI }\end{array}$ \\
\hline Anemia & 1,087 & 0,082 & 2,965 & $0,872-$ \\
& & & & 10,079 \\
\hline KPD & 1,018 & 0,027 & 2,769 & $1,126-$ \\
& & & & 6,811 \\
\hline Constant & $-0,670$ & 0,011 & 0,512 & \\
\hline
\end{tabular}

2 Log likelihood $=147,944 \quad G=18,361 \quad p \quad$ value $=0,000$

Hasil analisis diatas ternyata variabel anemia mempunyai $\mathrm{p}$ value sebesar 0,082 . Dengan hasil ini berarti variabel anemia dikeluarkan dari model. Kemudian diproses lagi dengan hanya mengikutkan variabel KPD. Hasil model tanpa variabel paritas terlihat pada model kelima berikut ini :

\section{Model 5.}

Hasil Analisis Multivariat Regresi Logistik antara KPD dengan kelahiran Preterm

\begin{tabular}{lcccc}
\hline Variabel & B & $\begin{array}{c}\boldsymbol{p} \\
\text { wald }\end{array}$ & OR & $\begin{array}{c}\mathbf{9 5 \%} \\
\text { CI }\end{array}$ \\
\hline KPD & 1,475 & 0,000 & 4,369 & $2,025-$ \\
& & & & 9,424 \\
\hline Constant & $-0,670$ & 0,011 & 0,512 & \\
\hline
\end{tabular}

$2 \quad$ Log likelihood $=151,22 \mathrm{G}=15,133$ $p$ value $=0,000$

Hasil diatas terlihat variabel KPD mempunyai $\mathrm{p}$ value $<0,05$ yaitu 0,000 , hal ini menunjukkan variabel KPD berhubungan secara signifikan dengan kelahiran preterm.

\section{PEMBAHASAN}

1. Hubungan antara umur ibu dengan kelahiran preterm

Dari hasil analisis univariat, sebagian besar ibu dengan umur risiko rendah yaitu umur 20-35 tahun sejumlah $67(55,8 \%)$ dan ibu dengan umur risiko tinggi yaitu < 20 atau $>35$ tahun sejumlah 53 (55,8\%).

Hasil analisis bivariat menunjukkan dari responden dengan umur risiko tinggi terdapat $31(51,7 \%)$ yang mengalami kelahiran preterm dan dari responden dengan umur risiko rendah terdapat $29(48,3 \%)$ yang mengalami kelahiran preterm. Hasil analisis diperoleh $p$ value 0,141 , ini menunjukkan tidak ada hubungan yang signifikan antara umur ibu dengan kelahiran preterm.

Hal ini tidak sesuai dengan teori Wiknjosastro (2007) yang menyatakan bahwa umur ibu $<20$ tahun atau > 35 tahun merupakan salah satu faktor predisposi terjadinya kelahiran prematur. Hal ini juga tidak sesuai dengan buku Buku acuan nasional pelayanan kesehatan maternal dan neonatal (Saiffudin, 2006) yang menyatakan usia ibu < 18 tahun atau > 40 tahun merupakan salah satu faktor penyebab kelahiran prematur. 
Kejadian partus prematur pada ibu dengan usia $<20$ tahun atau $>35$ tahun merupakan salah satu faktor predisposisi terjadinya kelahiran prematur. Hal ini dikarenakan pada usia $<20$ tahun sistem reproduksinya tidak siap dalam menerima kehamilan dan pada usia > 35 tahun fungsi dari alat reproduksi sudah menurun sehingga akan mempengaruhi kehamilannya. Sedangkan kejadian partus prematur pada ibu dengan usia reproduksi sehat juga dipengaruhi oleh berbagai faktor lain yang mempengaruhi seperti faktor idiopatik yang apabila penyebab partus prematur tidak dapat diterangkan, faktor latrogenik yang apabila kelangsungan kehamilan dapat membahayakan janin ataupun ibu sehingga menyebabkan kelahiran prematur buatan, kemudian faktor sosio demografik seperti kecemasan, stress, pekerjaan ibu, perilaku ibu, ataupun kondisi sosio ekonomi, serta faktor maternal seperti inkompetensi serviks, pernah mengalami partus prematur, interval kehamilan, kehamilan multijanin, ataupun karena infeksi.

Pada penelitian sebelumnya ibu yang berusia $<20$ tahun berisiko sebesar 5,04 kali untuk melahirkan prematur (CI:1,75-14,49 nilai $\mathrm{p}=0,0025)$, sedangkan ibu yang berusia $\geq 35$ tahun memiliki resiko 1,15 kali untuk melahirkan prematur dibandingkan dengan ibu hamil yang berusia 20-34 tahun (CI:0,61-2,16) (Irmawati, 2010).

Tidak adanya hubungan antara umur ibu dengan kelahiran preterm pada penelitian ini bisa disebabkan karena dari kelompok kasus kelahiran preterm, persentase umur ibu risiko tinggi dan umur ibu risiko rendah tidak jauh berbeda yaitu $51,7 \%$ da $48,3 \%$. Data penelitian juga didapatkan sekitar $20 \%$ ibu dengan umur risiko rendah mengalami kelahiran preterm yang disebabkan oleh KPD.

\section{Hubungan paritas dengan kelahiran preterm}

Hasil analisis univariat menunjukkan sebagian besar responden dengan paritas risiko rendah yaitu jumlah kelahiran 2-4 sebanyak 72 $(60 \%)$ dan hanya $48(40 \%)$ responden dengan paritas risiko tinggi.

Hasil analisis bivariat menunjukkan dari responden dengan paritas risiko tinggi terdapat $28(46,7 \%)$ yang mengalami kelahiran preterm dan dari responden dengan paritas risiko rendah terdapat $32(53,3 \%)$ yang mengalami kelahiran preterm. Hasil analisis diperoleh $p$ value 0,192, ini menunjukkan tidak ada hubungan yang signifikan antara paritas dengan kelahiran preterm.

Hasil penelitian ini tidak sejalan penelitian yang dilakukan Agustiana (2012) yang menunjukkan nilai $\mathrm{p}=$ 0.000 dan nilai OR 1.6 (95\%CI: $1.278-$ 2.054). Hal ini menunjukkan ibu yang primipara memiliki peluang 1.5 kali untuk bersalin prematur dibandingkan ibu yang multipara (95\%CI: 1.2751.716).

Namun pada penelitian lain menunjukkan bahwa ibu yang melahirkan anak pertama akan mengurangi risiko terjadinya persalinan prematur sebesar 0,56 kali dibandingkan dengan yang melahirkan anak lebih dari 1 (CI:0,33-0,97) (Irmawati, 2010).

Menurut Institute Medicine dalam Sastrawinata (2004) menyatakan ibu dengan paritas tinggi (melahirkan lebih dari 3 kali) cenderung mengalami komplikasi dalam kehamilan yang akhirnya berpengaruh pada hasil persalinan. Ibu dengan paritas di atas 3 , secara fisik sudah mengalami 
kemunduran untuk menjalani kehamilan yang tidak mudah. Paritas tinggi merupakan paritas rawan karena banyak kejadian obstetri patologi yang bersumber pada paritas tinggi, antara lain preeklampsi, perdarahan antenatal sampai atonia uteri. Hal ini disebabkan pada ibu yang lebih dari satu kali mengalami kehamilan dan persalinan fungsi reproduksi telah mengalami penurunan (Sunitri, 2008).

Tidak ada hubungan antara paritas dengan kelahiran preterm pada penelitian ini bisa disebabkan karena jumlah responden dengan paritas risiko tinggi yang mengalami kelahiran preterm tidak berbeda jauh dengan responden dengan paritas risiko rendah yang mengalami kelahiran preterm yaitu $28(46,7 \%)$ dan $32(53,3 \%)$.

\section{Hubungan Anemia dengan kelahiran preterm}

Hasil analisis univariat menunjukkan sebagian besar responden tidak mengalami anemia yaitu 94 responden $(78,3 \%)$ dibandingkan responden yang anemia yaitu 26 responden $(21,7 \%)$.

Hasil analisis bivariat menunjukkan dari responden yang mengalami anemia ada 21 responden $(35 \%)$ yang mengalami kejadian persalinan prematur dan dari responden yang tidak anemia terdapat $39(65 \%)$ yang mengalami persalinan prematur. Dari hasil uji statistik chi-square diperoleh nilai $\rho$ value sebesar $0,001<\alpha$ $=0,05)$. Hal ini berarti ada hubungan yang bermakna antara anemia dengan kelahiran preterm. Berdasarkan hasil analisis diperoleh pula nilai $\mathrm{OR}=5,923$ artinya ibu yang bersalin yang mengalami anemia mempunyai peluang 5,923 kali untuk terjadi kelahiran preterm dibandingkan responden yang tidak anemia.
Hasil penelitian ini sejalan dengan penelitian Romadhon (2016) yang menunjukan bahwa pada kelompok persalinan preterm lebih banyak ibu hamil anemia $(70,8 \%)$ dibandingkan ibu hamil tidak anemia (29,2\%). Pada kelompok persalinan aterm lebih banyak ibu hamil tidak anemia $(63,9 \%)$ dibandingkan ibu hamil anemia $(36,1 \%)$. Berdasarkan hasil uji statistik Chi-square didapatkan nilai $\mathrm{p}=0,018$, sehingga dapat disimpulkan bahwa terdapat hubungan bermakna antara anemia pada ibu hamil dengan kejadian persalinan preterm $(p<0,05)$.

Manuaba (2010) juga menambahkan bahaya anemia terhadap janin yaitu anemia akan mengurangi kemampuan metabolisme tubuh sehingga menganggu pertumbuhan dan perkembangan janin dalam rahim. Akibat anemia dapat terjadi gangguan dalam bentuk abortus, kematian intrauterin, persalinan prematuritas, berat badan lahir rendah, kelahiran dengan anemia, dapat terjadi cacat bawaan, bayi mudah mendapat infeksi sampai kematian perinatal, dan inteligensia rendah.

Menurut Karasahin et al., (2012) pada ibu hamil dengan anemia terjadi gangguan penyaluran oksigen dan zat makanan dari ibu ke plasenta dan janin, yang mempengaruhi fungsi plasenta. Fungsi plasenta yang menurun dapat mengakibatkan gangguan tumbuh kembang janin. Anemia pada ibu hamil dapat mengakibatkan gangguan tumbuh kembang janin, prematur, abortus, partus lama, sepsis puerperalis, kematian ibu dan janin, meningkatkan risiko berat badan lahir rendah, asfiksia neonatorum. Penelitian ini sejalan dengan penelitian Tarwoto (2010), menyebutkan bahwa anemia pada ibu hamil berhubungan dengan kejadian persalinan prematur. Ibu dengan anemia 
berisiko untuk melahirkan prematur disebabkan karena kurangnya kadar hemoglobin untuk mengikat oksigen yang akhirnya akan mengganggu suplai oksigen pada metabolisme ibu.

Peneliti berpendapat bahwa anemia berupa kondisi ibu dengan kadar hemoglobin di bawah 11 gr \% yang menyebabkan kurangnya darah, dimana jumlah sel darah merah atau hemoglobin (protein pembawa oksigen) dalam sel darah merahnya di bawah normal. Anemia berperan pada peningkatan prevalensi kematian dan kesakitan ibu, dan bagi bayi dapat meningkatkan resiko kesakitan dan kematian bayi serta persalinan prematur.

\section{Hubungan PEB dengan kelahiran preterm}

Hasil analisis univariat menunjukkan sebagian besar responden tidak mengalami PEB yaitu $84(70 \%)$ dibandingkan dengan responden yang mengalami PEB yaitu 30 (30\%).

Hasil analisis bivariat menunjukkan dari responden yang PEB terdapat $24(40 \%)$ yang mengalami kelahiran preterm dan dari responden yang tidak PEB terdapat $36(60 \%)$ yang mengalami kelahiran preterm. Dari hasil uji statistik chi-square diperoleh nilai $\rho$ value sebesar $0,028<\alpha=0,05)$. Hal ini berarti ada hubungan yang bermakna antara PEB dengan kelahiran preterm. Berdasarkan hasil analisis diperoleh pula nilai $\mathrm{OR}=2,667$ artinya $\mathrm{ibu}$ bersalin yang mengalami PEB mempunyai peluang 2,667 kali untuk terjadi kelahiran preterm dibandingkan responden yang tidak PEB.

Pada ibu dengan preeklampsia berat, persalinan harus terjadi dalam 24 jam, sedangkan pada ibu dengan eklampsia dalam 12 jam sejak gejala eklampsia timbul. Jika terjadi gawat janin, atau persalinan tidak dapat terjadi dalam 12 jam (pada eklampsia), maka dilakukan seksio seksarea. (Saifuddin, 2002).

Hasil penelitian ini tidak sejalan dengan penelitian terdahulu yang didapatkan bahwa ibu bersalin dengan preeklamsi berat yaitu sebanyak 41 $(59,4 \%)$ dan tidak mengalami partus prematurus sebanyak $28(40,6 \%)$, dan sebagian kecil ibu dengan preeklamsi ringan sebanyak $28 \quad(40,6 \%)$ dan mengalami partus prematurus sebanyak $1(1,4 \%)$. Menurut hasil penelitian didapatkan bahwa nilai hitung $=8,144$ dan tabel $=3,481$ taraf signifikan 0,05 dan $\mathrm{df}=1$, dengan demikian didapatkan hitung > tabel $(8,144>3,481), \mathrm{df}=1$. Jadi berdasarkan uji Chi Square didapatkan bahwa preeklamsi memberikan hubungan yang signifikan $(\mathrm{p}<0,05)$ dengan angka kejadian partus prematurus disimpulan hasil penelitian ini adalah ada hubungan antara preeklamsi dengan angka kejadian partus prematurus (Maryunani, 2011).

Hasil penelitian ini tidak sejalan dengan penelitian yang menunjukkan hubungan yang signitifikan antara ibu preeklampsia dan kejadian berat bayi lahir rendah dengan resiko kejadian untuk terjadinya berat bayi lahir rendah pada ibu yang menderita preeklampsia sebesar 6,292 yang berjudul Hubungan preeklamsi/eklamsi dengan kejadian berat badan lahir rendah (BBLR) di Rumah Sakit Katolik St.Vincentius A Paulo Surabaya (Yongki, 2014).

Berdasarkan teori dijelaskan bahwa kejadian kelahiran prematur yang dipengaruhi oleh preeklamsi / eklamsi akibat terjadinya spasmus pembuluh darah. Menurunya aliran darah ke plasenta mengakibatkan gangguan fungsi plasenta. Spasme arteriol yang mendadak dapat menyebabkan asfiksia berat. Jika 
spasme berlangsung lama akan mengganggu pertumbuhan janin. Jika terjadi peningkatan tonus dan kepekaan uterus terhadap rangsangan dapat menyebabkan partus prematurus. Menurunnya aliran darah ke plasenta mengakibatkan gangguan fungsi plasenta. Pada hipertensi yang agak pertumbuhan janin terganggu, pada hipertensi yang lebih pendek bisa terjadi gawat janin sampai kematian karena kekurangan oksigen. Kenaikan tonus uterus dan kepekaan terhadap perangsang sering didapatkan pada preeklamsi dan eklamsi, sehingga mudah terjadi partus prematurus (Wiknjosastro, 2006).

Asumsi peneliti yang ada bahwa preeklamsi pada ibu hamil dapat berakibat mengganggu dan menghambat aliran darah yang berfungsi dan pertumbuhan janinnya menjadi lambat diperlukan pengobatan secara terkontrol untuk ibu hamil dengan preeklamsi karena untuk menghindari resiko pada saat hamil dan pada saat bersalin diantaranya persalinan prematur. Akibat dari suplai zat-zat gizi dan oksigen untuk kebutuhan janin yang terhambat, sehingga terjadinya janin tumbuh lambat dalam lahir dan akhirnya melahirkan dengan persalinan prematur.

\section{Hubungan KPD dengan kelahiran preterm}

Hasil analisis univariat menunjukkan sebagian besar responden tidak mengalami KPD yaitu $65(54,2 \%)$ dan hanya $55(45,8 \%)$ yang mengalami KPD.

Hasil pembahasan bivariat menunjukkan dari 60 responden yang mengalami kelahiran preterm, ada 38 responden $(63,3 \%)$ yang mengalami ketuban pecah dini dan dari responden yang tidak KPD terdapat $22(36,7 \%)$ yang mengalami kelahiran preterm. Dari hasil uji statistik chi-square diperoleh nilai $\rho$ value sebesar $0,000<\alpha$ $=0,05)$. Hal ini berarti ada hubungan yang bermakna antara KPD dengan kelahiran preterm. Berdasarkan hasil analisis diperoleh pula nilai $\mathrm{OR}=4,369$ artinya ibu bersalin yang mengalami KPD mempunyai peluang 4,369 kali untuk terjadi kelahiran preterm dibandingkan responden yang tidak KPD.

Hasil analisis multivariat juga menunjukkan bahwa variabel KPD adalah variabel yang paling dominan berpengaruh dengan kelahiran preterm, ini ditunjukkan dengan nilai $p$ value 0,000 .

Hal ini sesuai dengan teori menurut Manuaba (2012) yang menyatakan bahwa pecahnya selaput ketuban disebabkan karena selaput ketuban tidak kuat akibat kurangnya jaringan ikat dan vaskularisasi. Akibatnya selaput ketuban yang berfungsi melindungi atau menjadi pembatas dunia luar dan ruangan dalam rahim pecah dan mengeluarkan air ketuban yang menyebabkan hubungan langsung antara dunia luar dan ruangan dalam rahim yang memudahkan terjadinya infeksi asenden. Semakin lama periode laten maka semakin besar kemungkinan infeksi dalam rahim, persalinan prematur dan selanjutnya meningkatkan kejadian kesakitan dan kematian bayi atau janin dalam rahim.

Hal ini sesuai dengan penelitian Agustina (2012) yang menyatakan bahwa Persalinan prematur pada ibu yang mengalami ketuban pecah dini yaitu sebesar $17.3 \%$, sedangkan pada ibu tidak bersalin prematur yang mengalami ketuban pecah dini yakni sebesar 5.4\%. Hasil uji statistik menunjukkan nilai $\mathrm{p}=0.000$ dengan nilai $\mathrm{OR}=3.7$ (95\% CI: 3.003-4.493). 
Hal ini menunjukkan ibu yang mengalami ketuban pecah dini mempunyai peluang 3.7 kali persalinan prematur dibandingkan dengan ibu yang tidak mengalami ketuban pecah dini

Pecahnya selaput janin dan terjadi pengeluaran air ketuban sebelum persalinan dimulai dapat memberikan kesempatan terjadinya infeksi langsung pada janin. Sebab terjadinya selaput janin pecah diantaranya karena trauma langsung pada perut ibu, kelainan letak janin dalam rahim, atau pada kehamilan grandemultigravida (hamil lebih dari lima kali). (Manuaba, 2017).

Berdasarkan penelitian ini KPD bisa dihubungkan dengan kelahiran preterm karena ketika selaput ketuban pecah pada umur kehamilan kurang dari 37 minggu secara langsung ketuban pecah dan menimbulkan kontraksi sehingga merangsang mulut rahim membuka dan menimbulkan persalinan prematur.

Dari hasil analisis multivariat dalam penelitian ini, KPD sebagai faktor yang paling dominan mempengaruhi kelahiran preterm di RSUD Banyuasin. Hal ini ditinjau dari nilai explanatory $B(\exp B)$ variabel KPD sebesar 4,369 lebih besar daripada nilai $\exp B$ variabel anemia 2,965.

Ketuban pecah dini adalah keadaan pecahnya selaput ketuban sebelum persalinan. Bila ketuban pecah sebelum usia kehamilan 37 minggu disebut ketuban pecah dini pada kehamilan preterm. Dalam keadaan normal $8-10 \%$ perempuan hamil aterm akan mengalami KPD. KPD premature terjadi $1 \%$ kehamilan. Pecahnya selaput ketuban berkaitan dengan perubahan proses biokimia yang terjadi dalam kolagen matriks ekstra selular amnion, korion dan apoptosis membran janin. Setelah ketuban pecah biasanya segera disusul oleh persalinan. Periode laten tergantung umur kehamilan. Pada kehamilan aterm 90\% terjadi dalam 24 jam setelah ketuban pecah, pada kehamilan antara 28-34 minggu 50\% persalinan dalam 24 jam. Pada kehamilan kurang dari 26 minggu persalinan terjadi dalam 1 minggu (Sarwono, 2011).

Berdasarkan hasil penelitian ini KPD bisa dihubungkan dengan kejadian kelahiran preterm karena ketika selaput ketuban pecah saat usia kehamilan kurang dari 37 minggu, secara langsung ketuban pecah dan menimbulkan kontraksi sehingga merangsang mulut rahim membuka dan menimbulkan terjadinya kelahiran preterm.

\section{KESIMPULAN}

1. Tidak ada hubungan yang signifikan antara umur ibu dengan kelahiran preterm $(p=0,098)$.

2. Tidak ada hubungan yang signifikan antara paritas dengan kelahiran preterm $(p=0,136)$.

3. Ada hubungan yang signifikan antara anemia dengan kelahiran preterm $(p=0,000)$.

4. Ada hubungan yang signifikan antara KPD dengan kelahiran preterm $(p=0,000)$.

5. Ada hubungan yang signifikan antara PEB dengan kelahiram preterm $(p=0,017)$.

6. Variabel yang paling berpengaruh terhadap kelahiran preterm adalah KPD $(\mathrm{OR}=4,369)$.

\section{SARAN}

1. Diharapkan petugas kesehatan agar memberikan konseling sebelum dan saat kehamilan sehingga anemia, ketuban pecah dini, preeclampsia / eklampsia dapat dicegah dan tidak sampai berdampak persalinan prematur. 
2. Diharapkan dalam antenatal care memberikan pelayanan sesuai standar yang ditentukan dan mengingatkan pasien untuk kembali pada pemeriksaan selanjutnya agar frekuensi minimal antenatal care dapat terpenuhi.

3. Menekankan kepada setiap bidan atau petugas kesehatan untuk rutin melakukan pemeriksaan kadar hemoglobin ibu hamil sehingga bidan dapat mengecek dan memantau langsung status anemia ibu sejak awal kehamilan.

\section{DAFTAR PUSTAKA}

Agustiana,Tria. 2012. Faktor-faktor yang berhubungan dengan persalinan prematur di Indonesia tahun 2010 (Analisis Data Riskesdas 2010). FKM UI. Jakarta.

Irmawati. 2010. Pengaruh Anemia Ibu Hamil dengan terjadinya Persalinan Prematur di Rumah Sakit Ibu dan Anak Budi Kemuliaan Jakarta. Tesis FKM UI. Jakarta.

Marisa, Ip, Peyman,E, Lohsoontorm, V, Williams, M, A. 2010. A CaseControl Study of Preterm Delivery Risk Factors According to Clinical Subtypes and Severity. Dalam: http://web.ebscohost.com (20/04/2019).

Sastrawinata, S. 2004. Obstetri Patologi Ilmu Kesehatan Reproduksi Edisi 2. Bandung: EGC.

Sunitri. 2008. Kesehatan Reproduksi Wanita. Available online: www.radiodfm.com. 24 Maret 2019.

Kepmenkes. (2015). Kesehatan Dalam Rangka Sustainable Development Goals (SDGs). Jakarta:
http://www.Pusat2.litbang.depk es.go.id (Accessed 17 Maret 2019).

Putra, Hasibuan \& Fitriyati., 2014. Hubungan Persalinan Preterm pada Preeklamsia Berat dengan Fetal Outcome di RSU Islam Harapan Anda Tegal. Yogyakarta. JKKI.

Winkjosastro, H., 2006. Ilmu Kebidanan. Jakarta: Yayasan Bina Pustaka.

World Health Organization (WHO), 2015. [Online] Available at: http://www.who.int/mediacentre/facts heets/fs363/en/ (Accessed 20 April 2019).

Romadhon, Muhamad. 2016. Hubungan Preeklampisa, Plasenta Previa dan Anemia Terhadap Kejadian Persalinan Prematur di RS TK.II Dr. AK Gani Palembang Tahun 2016. Universitas Kader Bangsa Palembang.

Rizal,.2012. Memprediksi Preeklamsia Dexa Media . No 1, Vol 21. Januari-Maret 2008, http://www.dexamedia.com/images/p ublication_jan_mar_08.pdf. diunduh tanggal 2 april 2019.

Maryunani, Anik dan Yulianingsih. 2011. Asuhan Kegawatdaruratan Dalam Kebidanan. Jakarta : CV Trans Info Media.

Yongky Gousario. 2014. Hubungan Preeklampsia Dengan Kejadian Berat Bayi Lahir Rendah Di Rumah Sakit Katolik St. Vincentius A Paulo Surabaya Tahun 2013 http://repository.wima.ac.id/1259/1/ Abstrak.pdf diunduh tanggal 2 april 2019. 
Yulianti. 2013. Asuhan Kebidanan Patologi Kebidanan. Perpustakaan Nasional: KDT jakarta. 